\title{
Sexual Cell Fusions and Vegetative Nuclear Divisions in the Rusts.
}

\author{
BY
}

EDGAR W. OLIVE.

\section{With Plate XXII.}

WE owe to the recent important discoveries of Blackman ('04) and Christman ('05) our knowledge as to the existence of a process of sexual reproduction which occurs at a certain stage in the development of the Rusts. Their accounts conflict somewhat, however, in respect to the mode of origin of the binucleated condition; hence the need of still further work on the cytology and minute structure of these forms. The following research explains to a certain extent some of the discordant results of the two accounts just mentioned, and at the same time extends our rather limited knowledge of the nuclear division in the vegetative cells. Further, the discovery of multinucleated cells at the base of certain aecidia, which may possibly be identical with the archicarps of De Bary, Massee, and Richards, obviously shows the urgent need of an investigation of the structure and development of further types of the aecidium-cup, before we shall be able to understand the possible connexion of this type of fructification with the simpler caeoma type, as well as its relationship to the fruit-bodies of other Fungi and Algae.

Earlier views as to the way the binucleated cells have arisen have been sufficiently reviewed in the papers of the writers just mentioned; hence a brief summary here will suffice. Rosen ('92) regarded the two nuclei in the aecidiospores as sister nuclei. The basal cell of the row of spores starts, according to him, with one large nucleus, which divides, and the upper of the two resulting daughter-nuclei at once divides again, this time at right angles to the axis of the elongated cell. The two nuclei thus formed in the apical end of the basal cell are then cut off by a cross wall from the one nucleus below, and thus form the beginning of the binucleated series. The uninucleated basal cell left below proceeds to divide again, and another binucleated cell follows as described.

Poirault and Raciborski ('95) apparently thought that the binucleated condition started in the sporidium, which they found sometimes contained two nuclei. They emphasized the fact, however, that the two nuclei which finally fuse in the teleutospore have no close relationship, since each has

[Annals of Botany, Vo1. XXII. No. LXXXVII. July, I908.]

A a 
a distinct line of ancestors running far back in the life-history of the fungus.

Sappin-Trouffy ('96) also paid little attention to the origin of the binucleated condition, as he regarded the fusion of nuclei in the teleutospore as the most important stage in the sexual cycle. Poirault and Raciborski, as well as Maire, opposed this view, since they did not consider the fusion in the teleutospore as a sexual act.

Richards ('96) concluded that the binucleated cells in the Rusts had but little significance, since he thought 'that they are found in all of the other parts of the aecidia, in the hyphae, the pseudoparenchyma, and the peridium' (p. 260). Richards further considered the aecidium as more or less of a morphological unit, for he found at the base of the cup one, or occasionally more, large, sometimes multinucleated, cells which, according to him, give rise by budding to the basal cells at the bottom of each chain of spores. He was not able to trace the origin of these multinucleated cells.

Maire ('00), to whom we are indebted for first pointing out the existence of an alternation of generations in the Rusts, finds that in Endophyllum the vegetative hyphae are made up of uninucleated cells, to the very base of the aecidium. The basal hyphae, as well as the single nucleus in each, enlarge greatly. The binucleated condition is now brought about, according to him, by simple division of this one nucleus, unaccompanied by cell-division. The binucleated series starts, then, with sister-nuclei.

Blackman and Christman, notwithstanding their conflict in certain important details, agree in the crucial point, viz. that two uninucleated cells contribute to the initiation of the binucleated series. The main contention involves the character of the fusing cells-Blackman maintaining that the fertilization in the Rusts is an oosporic process, Christman, on the other hand, holding that it is zygosporic.

Blackman ('04), working with Phragmidium violaceum, describes the binucleated condition as arising from a 'vegetative fertilization', consisting of the migration of a smaller nucleus from an ordinary vegetative cell into a special 'fertile, or female' cell, containing a somewhat larger nucleus. Such a reduced sexual process has come about, according to him, through the replacement of the now functionless male cell, or spermatium, by an ordinary vegetative cell. A simpler 'internal' fertilization thus replaces the former 'external' fertilization, in which the spermatium functioned. He argues that the spermatia are male cells because of their resemblance to the spermatia of lichens, and because of their dense nuclei, and their small amount of cytoplasm, thus resembling strikingly male cells. $\mathrm{He}$ finds it impossible to accept the conidial nature of the spermatia, because of the difficulty in imagining a process of degeneration which brings about 
a reduction of the cytoplasmic portion of the cell, but leaves the nuclei unchanged.

Each female reproductive organ, according to Blackman's conception, consists of a female cell below and a sterile cell above. He suggests that the sterile cell probably once pushed its way through the epidermis to the surface, and there functioned as a trichogyne, fusing with the spermatium. The vegetative nuclei migrate into the female cell either from the cell immediately below the female cell, in the same cell row, or from one of the smaller neighbouring cells at its base. The migration takes place, according to him, through a very small pore, that neither before nor after the passage of the nucleus could be distinguished. Whether any protoplasm passes over with the migrating nucleus Blackman could not determine.

Christman ('05), working with Caeoma nitens, Uromyces Caladii, and Phragmidium speciosum, described a process of true fertilization by the fusion of two cells, which he regarded as decidedly different from Blackman's method of nuclear migration. The two cells which fuse are of approximately equal size, as are also their nuclei. Both cells may, according to Christman, cut off sterile cells before becoming gametes. The fusing cells are figured as lying side by side, and a considerable portion of the walls in contact dissolve away, so that the product of the union is a distinct double cell, composed of the cytoplasm and nuclei from the two equal gametes. In harmony with this account, the row of spores formed from the growth of this fusion cell is regularly borne on two cells forming a double base. Blackman's basal cell, on the other hand, is really but one cell, with two nuclei. The latter contends that Christman's fusion occurs between two 'female cells'. Christman himself regards the fusion as rather of the nature of the conjugation of equal gametes, resulting in a non-resting zygospore.

Blackman and Fraser ('06), in their further studies on the sexuality of the Rusts, have investigated seven additional species, three for the development of the aecidia, three micro-forms, and one lepto-form. Nuclear migrations were found to be the means for the initiation of the binucleated condition in the aecidium cups of Uromyces Poae and Puccinia Poarum. In Melampsora Rostrupi, a caeoma form without pseudoperidium, the authors found indications of a conjugation of two equal cells, in the same manner as Christman described. They therefore now give equal rank to nuclear migration, or ' partial cell fusion', as they term it (p. 44), and fusion of two equal cells, as the mode of origin of the binucleated condition in the group.

Although convincing evidence was not obtained as to the method of transition from uninucleated to binucleated cells in the other four forms studied, the authors regard it as established that in the lepto-form, Puccinia malvacearum, the change to a conjugate condition takes place just before 
the formation of teleutospores; while in the three micro species, the fertilization occurs at some earlier point in the life-history, without any immediate relation to the development of the teleutospores.

In a second paper, Christman ('07') found that in the so-called 'primary uredo' form, Phragmidium potentillae-canadensis, the binucleated condition arises exactly as in the aecidium which he earlier described, by the fusion of two equal cells. He further emphasizes the interesting fact, also noted by Sappin-Trouffy, that the elongated stalk cells which bear the primary uredospores are plainly equivalent to the intercalary cells of the row of spores of the aecidium. Hence he argues that the primary uredo is morphologically an aecidium.

Still more recently, the same author $\left(07^{2}\right)$ has discussed the bearing of the facts, so far as known, on the general morphology of the various spore forms of the Rusts. He holds that the micro- and lepto-forms are the primitive Rusts and that the teleutospores are the primitive spores. The various other kinds of binucleated spores in the Rusts have been, therefore, gradually intercalated in the life-history. Christman holds that the binucleated 'basal cell' ('basidium' of certain older authors) is the morphological unit, since each subgeneration (bearing aecidio-, uredo-, or teleutospores) begins and closes with such a cell. The 'basal cell' produces its various kinds of spores in chains, or else singly, on long stalks, by a process of successive budding. He therefore concludes that the various kinds of sporophytic spores-aecidio-, uredo- (both primary and secondary), and teleutospores-are all homologous structures. The spermatia represent, in his opinion, the once functional asexual spores of the gametophyte ; and he points out that they are quite similar in structure and general appearance to the other gametophytic spores of the Rusts - the sporidiaas well as to the pycnidia of certain Ascomycetes.

He finds also in Puccinia Podophylli frequent cases of the migration of nuclei in the teleutospore sorus from one sporophyte cell into another. Since no fertilization can be assumed in such instances, Christman interprets the phenomenon as purely pathological, perhaps due to the wound received at the time of fixation. He is therefore inclined to interpret Blackman's nuclear migrations in the vegetative cells at the base of the aecidia of Puccinia Poarum, as well as in other cases, as occurrences of a similar pathological nature.

The process of nuclear division in the Rusts is much better known for the nuclei in the promycelium than for the vegetative nuclei. Poirault and Raciborski ('95) studied the nuclear divisions in various types of cells of the group, and have obtained some very exceptional results. Each nucleus is regarded as containing but a single chromosome, which, during mitosis, splits longitudinally. During conjugate division, the two dividing nuclei form, in their opinion, but one spindle. 
Sappin-Trouffy ('96) and Maire ('00), on the other hand, regard the two chromatin masses in each dividing nucleus, not as evidence of longitudinal splitting, but rather as showing that there are two chromosomes regularly present in the nuclei of the Rusts. While indirect division is described as the principal method of nuclear division, Sappin-Trouffy also finds cases of amitosis, especially in old mycelial cells.

Juel ('98), studying the promycelial divisions in Coleosporium, obtained results quite different from the authors mentioned above. His figures of nuclear division resemble closely those of other fungi. While not able to distinguish individual chromosomes, Juel thinks it quite probable that there are many.

Holden and Harper ('03) have recently shown that the process of division of the fusion nucleus of Coleosporium agrees in essential details with those described for higher plants. In the prophases, a spirem thread splits longitudinally. In the metaphases, polar radiations, centrosomes, spindle and chromosomes are all very sharply differentiated. The chromosome number is somewhere between six and ten. Conjugate division, in which the chromatin is represented as solid, dumbbell-shaped masses in all stages of division, is also figured by these authors; but they think it quite likely that poor fixation is responsible for the lack of differentiation.

Blackman ('04) has also investigated the subject of nuclear division, particularly in the promycelial cells of Gymnosporangium, and he has further compared with this type the divisions in the spermogonium, as well as the conjugate divisions in the sporophytic cells. The two divisions in the promycelium are regarded as reduced, or simple, forms of indirect division, while in the spermogonium and in the binucleated cells 'chromosome-formation is in complete abeyance, so that the division actually partakes of the nature of direct division (amitosis) ' (p. 356).

In the promycelial divisions, according to Blackman, a well-defined spindle, centrosomes, and polar radiations are present. In the first division many chromosomes - at least ten-are formed; but in the second division the chromosomes appear to lose their individuality, and to form a solid mass. Blackman regards the spindle in the case of the second division of the promycelial nuclei, and apparently also in the case of the first, as formed free in the cytoplasm between the two portions of a divided extranuclear centrosome, and therefore as similar to the 'Centralspindel' of Hermann. His figures showing divisions in the spermogonium and in the binucleated cells merely repeat the poorly differentiated structures brought out by former authors.

Finally, Christman ('05, ' $07^{1}$ ) has figured the anaphases of the conjugate division, showing the two distinct spindles, the several chromosomes (the number was not determined), and a few short rays attached to each pole. 


\section{MAterial AND Methods.}

I am much indebted to Professor J. C. Arthur for the privilege of collecting rust material from his laboratory cultures, and for suggestions as to the most promising forms for study, as well as for other courtesies. I wish to acknowledge my obligations, also, to the Carnegie Institution of Washington for a grant which has made possible this collection. Of the forty species and more examined, perhaps the most favourable form for the study of sexual cell-fusions, as well as of nuclear division, was found to be Triphragmium ulmariae (Schum.) Link, on Ulmaria rubra Hill, a caeoma form, similar to the Phragmidia studied by Blackman and Christman. Cell-fusions are shown most clearly and unmistakably in Triphragmium, particularly after the walls of the hyphae have been specially stained; and the nuclear divisions in the spermogonium, as well as in both the gametophytic and sporophytic cells, show many details not hitherto described. Other species in which cell-fusions are described in this paper are: Gymnoconia interstitialis (Schlecht.) Lagerh. (Caeoma nitens S.) on Rubus sp.; Phragmidium potentillae-canadensis Diet. on Potentilla canadensis; and the micro form, Puccinia transformans E. \& E. on Tecoma stans Juss.

Besides the fairly complete series of karyokinetic stages from Triphragmium, the following species have been utilized for isolated stages: Uromyces Scirpi (Cast.) Burr. (Aecidium Sii-latifolii Wint.) on Cicuta bulbifera, Uromyces Lilii Clint. on Lilium canadense and Puccinia Cirsiilanceolati Schroet. on Carduns lanceolatus L.

The material for the most part was fixed in various strengths of Flemming's Chromic-acetic-osmic acid mixtures. Some which was fixed in Juel's Zinc chloride-acetic-alcohol mixture proved to be particularly favourable for bringing out the cell-fusions, since the cell-walls seemed to color with especial tenacity after such fixation. With this method, absolutely convincing evidence was obtained as to conjugation pores, and as to the extent of absorption between fusing cells. Flemming's triple stain was used almost exclusively.

\section{Sexual Cell Fusions.}

Figs. 20-40, P1. XXII, inclusive, drawn from four species of Rusts, show the method by means of which the binucleated condition suddenly arises, following a period of growth which produces only uninucleated cells. All four of the species here represented are of the diffuse caeoma type of aecidium. Although I have also found cases of fusions in the aecidium-cup type, certain peculiarities present in such forms, to be discussed later to a limited extent in connexion with nuclear division, necessitate further study before these more complicated conditions can be brought in line with the simpler caeomas. 
As will be at once seen, all of the sexual fusions shown in Figs. 26-40 involve the conjugation of two uninucleated cells, through a pore of greater or less width. Further, since these figures are all similarly oriented, i. e. with the upper part of each figure pointed upward toward the top of the plate as toward the epidermis of the host, it is obvious that the fusing cells, at least so far as one can judge from sections, may be placed in almost any position with respect to each other. For example, the cells may be placed side by side, in the same plane, in much the same position as they are figured by Christman (Figs. 26, 27, 35, 36, 39, and 40). Perhaps even more frequently, in my experience, one of the fusing cells appears to lie somewhat below the other, as in Figs. 26, 28-34, 37, and 38, some of which suggest the conditions which Blackman figures (see, e. g. his Figs. 66-70).

Figs. 26-33 are all drawn from preparations of Triphragmium ulmariae. Fig. 26 represents a preparation in which two pairs of fusion-cells are shown side by side. Although at this stage in the development of the fungus sexual fusions may be found at many points along the diffuse sorus in the same section, one rarely meets with two such instances so near together, and at the same time properly oriented to serve for drawing. The boundaries of the cells below are lost in the mass of hyphae pushing up around them ; but the upper parts, showing the fusions, are quite clear. One nucleus from each pair is somewhat stretched out, apparently in the act of moving toward the other conjugating cell. In the instance at the left, however, the bud, which is put out after the fusion, is starting to grow in the opposite direction. One of the left pair in this case has a uninucleated cell above. Whether this is a 'sterile cell' or not, I am uncertain, since it stains quite darkly, and it does not appear to be in any way degenerating. In the other instance, however, at the right, the cell just under the epidermis is unmistakably a sterile cell, since it shows the characteristic signs of degeneration, both in its cytoplasm and in its nucleus. It is interesting to note that in this latter pair of cells the one is placed much lower than the other, and, further, the lower cell does not appear to have cut off any sterile cell at its tip. In the other pair at the left, the two cells at the time of fusing apparently had grown up to about the same level. The unusually long conjugation tube connecting the latter pair is another feature of especial interest.

In the next figure, 27 , several interesting features are shown. In the first place, the conjugating cells are placed parallel to each other and at about the same level. Further, the right gamete has a degenerating sterile cell attached at its tip, whereas the left gamete has none. The point of contact of the two cells is apparently rather a small area; hence the hole through which the fusion of the two protoplasts takes place is as yet comparatively small. The left nucleus is clearly moving over into the right half of the fusion-cell, so that it actually appears to have pushed into and slightly indented the other nucleus. It is quite possible that Blackman would 
maintain that this is a case of nuclear migration. At the same time, it is undoubtedly a case of cell fusion, and quite similar to those instances described by Christman in which conjugation has occurred between two cells lying side by side.

In Fig. 28 the relation which the two fusing cells sustain to each other is somewhat uncertain. Although the lower cell appears to belong to the same hypha as the upper, I doubt that this is the correct interpretation, for careful focussing seems to show that the lower cell is from a distinct hypha which comes up obliquely toward the eye. It is important to note here again that the upper cell has attached to its tip, just under the epidermis of the host, a degenerating cell; and also that the budding growth has begun even before the lower nucleus has passed over into the companion cell. Many similar instances to the one figured show that the bud generally pushes out to one side of the sterile cell, instead of crushing directly into the latter.

Fig. 29 shows a much later development, in which the second bud has started off from the binucleated fusion cell. Even at this late stage, the interesting fact may be noted that two distinct cells enter into the composition of the fusion cell, or basal cell. The two nuclei lie, however, in the upper gamete. The remnant of the old wall, which formerly separated the two gametes, and through which the conjugation took place, is very sharply brought out in the figure, although it has apparently been almost completely absorbed. The younger bud at the right is cut obliquely lengthwise at its tip; hence its peculiar irregular shape, instead of the usual form with rounded end. An old dead sterile cell, not shown in the drawing, lies between the two buds. It probably once belonged to the upper of the two fused cells, but the rapid growth which followed the conjugation has displaced it from its original position. The larger bud in this case, although it has been cut off by a wall from the basal cell, does not yet constitute a spore, since a stalk will first be cut off below, to bear the oval spore at its tip. That the two nuclei of this bud are, in fact, in the prophases of conjugate division is indicated by the vacuolated condition of the nucleoli, and by the appearance of the chromatin. The same is true for the two nuclei below, but neither pair is adapted to show the minuter details of the process. Still later stages, in which the binucleated basal cell has successively budded off, in the manner indicated in Fig. 29, several spores, each borne on a slender binucleated stalk, are abundant in the same preparation. The method of formation of the primary uredospores of Triphragmium, therefore, agrees exactly with that described by Christman ('07') for Phragmidium potentillaecanadensis, thus adding further confirmatory evidence to Christman's contention that the primary uredospores are morphologically equivalent to the catenulate aecidiospores.

Figs. $30-33$ show still further variations in the relative positions of the 
two conjugating cells of Triphragmium. In all these cases, one of the conjugants lies below the other, either immediately or else obliquely below. But, as has been intimated above, the evidence is not at all conclusive that in any case the two cells are derived from the same hypha. In fact, wherever positive evidence is present, it points out that the two cells are entirely distinct, and are not related as granddaughter cells of the same hypha, as Blackman thinks may be the case sometimes.

In Fig. 30 the partially absorbed partition wall between the two gametes appears to be peculiarly bent and contorted. The two nuclei now lie close together, and the fusion cell shows evidence of considerable growth. In Fig. 3I fusion has apparently just taken place, and the prophases of nuclear division have already begun. The sterile cell in this figure is particularly interesting. It has swollen up to an unusual size; further, the process of degeneration appears to have left but little of the cytoplasmic and nuclear contents, other than the more resistant nucleole.

Fig. 32 proves conclusively the statement made above, that the karyokinetic processes begin at once, on the very initiation of cell fusion, and some time before the gamete nuclei come to lie close together; since the migrating nucleus has cast out and left behind in the lower gamete its nucleole. As will be seen later, this throwing out of the nucleole is one of the first indications of mitosis.

Figs. 33 and 34 show conditions of particular interest, the significance of which will be discussed later, since in both instances nuclei from a lower cell are apparently migrating into an upper cell. Fig. 33 is from Triphragmium, while Fig. 34 is from a preparation of Gymnoconia interstitialis. These figures are both quite comparable to Blackman's Figs. 66 and $68 . \quad$ In neither of my figures, however, is there such a tiny pore present as must be assumed to be the case in Blackman's Figs. 67,69 , and 70 , where the migrating nuclei are drawn out to narrow threads in the process. Figs. 33 and 34 simply represent cases in which the fusion of the two cells is initiated by the beginning of the passage of the protoplast through a very small pore. In Fig. 33 the nucleus has just begun to pass through from the lower into the upper cell. Both gametes are obviously from distinct hyphae in this instance, as are also those of Fig. 34. In the latter figure, fully half of the long, stretched-out nucleus has passed through the narrow opening into the upper cell, and now partially overlies the nucleus of the upper cell.

Figs. 35 and 36 represent also cell fusions in Gymnoconia ; both are of a similar type, in that the fusion occurs between two cells placed adjacent and parallel. These figures recall Christman's ('05) Fig. 5, in which one gamete lies slightly higher than the other. It is a highly interesting fact, and one which will call for comment later, that Figs. 34 and $3^{6}$ are drawn from the same section, and are situated only a short distance from each other in the preparation. Here appears to be an instance in which 
a Blackman 'nuclear migration' occurs adjacent to a case of 'cell fusion' similar to that described by Christman.

Figs. 35 and 36 , as indicated above, are quite similar to each other as to their method of fusion. In Fig. 35, however, the walls below, between the two gametes, are shown as one; while in the other figure the walls are quite distinct from each other. In both cases, further, a concentration of finely granular protoplasm is evident in the upper part of the fused cells, where the protoplasts have mixed in, and on either side of, the conjugation pore. In Fig. 35, finally, each nucleus shows a small, deeply stained, dumbbell-shaped body - the dividing centrosome-whose significance will be discussed in some detail later.

Fig. 37, from a preparation of Phragmidium potentillae-canadensis, although poorly stained as to the nuclei, shows very clearly the beginning of the formation of the conjugation pore. Here again the relation of the two cells to each other is in doubt. Although they appear to be in the same cell row, the lower cell may just as well be from one of the obliquely lying hyphae which come up from below at varying angles. In this figure, a granular body, resembling a nucleole, lies in the pore connecting the two cells. In other cases I have found unmistakable cases of nucleoles thus thrown out at the beginning of the nuclear division, which starts with the earliest indication of cell fusion. But in this instance vacuolated nucleoles are apparently still present in both poorly-defined nuclei, so that it seems likely that the granular body is merely a cytoplasmic inclusion.

Fig. 38 is from the same preparation of Phragmidium potentillaecanadensis as is Fig. 37. Such poorly fixed and stained preparations were thus selected because the remnant of the partition wall between the two fused cells stands out in each case with great distinctness. The leaf in this instance was fixed with Juel's fixative and stained with Flemming's triple stain, as was also the material from which Figs. 28-32 were drawn.

Figs. 39 and 40 represent fusing cells of the micro-form, Puccinia transformans. In the first-named figure, the nuclei, except for their bright red nucleoles, are not well defined. Fusion has apparently taken place in this instance between the tips of two parallel hyphae. In Fig. 40, on the other hand, an end cell of one hypha (which apparently comes in obliquely from below) has fused with the penultimate cell of another. The uninucleated character of the gametophytic cells is also well shown in the latter figure. While it is not my present purpose to discuss this micro-form in detail, I may say in passing that the fusion is followed at once by a growth resulting in teleutospores, each borne on a stalk consisting, at least in some instances, of about three binucleated cells. The sporophytic development consists, therefore, of a few binucleated cells only. This case is possibly similar to that of Puccinia malvacearum, in which Blackman finds that the change from a uninucleated to a binucleated condition occurs at the base of 
the teleutospore sorus, although he is quite at a loss to explain how the transition has come about.

\section{Vegetative Nuclear Division.}

As indicated in the review of the present status of our knowledge concerning the nuclear division in the Rusts, the subject greatly needs further investigation. Triphragmium ulmariae proved to be an especially favourable form, since the large nuclei show in their division stages many details not hitherto described. The caeoma-like aecidium of the thistle Rust as well as some other forms were also found to possess comparatively large nuclei, but the mitotic figures were not so clear in these species.

Fig. I shows one of the exceptionally large nuclei characteristic of the spermogonial hyphae of Triphragmium. A comparison of Fig. I with Figs. I2, 26, and 27 , which are drawn to the same scale, will serve to emphasize the difference in size between the nuclei of the spermogonium and those of the germ cells of the young sporophyte. In Fig. I will be seen a small nucleole, a lightly-staining chromatin network, and, in particular, two small, deeply-staining bodies on the nuclear membrane, each surrounded by a small aggregation of a less deeply-staining archoplasm-like substance. These two centrosomes, as I shall term them, now lie close together, and each has attached to it a well-defined chromatic filament. I am inclined to think that this figure represents an early prophase condition, in which the centres have just undergone division; but there is another possible view, which will be explained in some detail later, viz. that the two centres have been carried over as a double centre from the last previous division.

Fig. 2 is much easier to interpret. The two distinct centres shown in this figure have obviously migrated apart, until they now lie at quite a distance from each other, and they are joined together by a long, slender strand. Judging from careful focussing, the strand apparently lies uppermost, on the surface of the nucleus, which still contains some nuclear sap and is still enclosed in a nuclear membrane. In this figure it is clear that the deeply-staining chromatin, particularly in the basal portion, is attached partly to the centres, and, at least apparently, partly to the narrow strand itself. As will perhaps be more clearly seen in figures of conjugate division, to be explained later, this strand connecting the diverging centres undoubtedly corresponds to the 'Centralspindel' of Hermann ('91).

In the next figure, 3 , which is somewhat more highly magnified, the central spindle now extends to the extreme ends of the elongated nuclear figure. Apparently the nuclear membrane has not yet completely broken down, as some sap still seems to be present in the lower part of the nucleus. The nuclear content in the upper half of the figure, in the spermatial bud, is obscure. It appears to be composed mainly of a thready substance. The chromatin obviously lies at one side of the spindle figure, and apparently 
almost entirely in the lower, more swollen part of the nucleus. Whether this nucleus has yet passed through the equatorial-plate stage I am not able to state positively, as this stage is somewhat obscure for the spermogonial nuclei of Triphragmium. This phase is more clearly brought out in the later sporophytic divisions.

Fig. 4 shows a somewhat later stage of division in the spermatial filament of Triphragmium. This seems to be an early anaphase, since some of the chromatin still occupies a more or less central position, while other chromatin material has already been drawn closer to the poles. The central spindle is here shown to be a rather thick, achromatic strand, situated a little to one side of the axis of the figure, while the mantle fibres are also more or less clearly defined, having one end attached to the poles, and extending thence along the axis as granular filaments, which appear to be mostly chromatic in their staining reactions. An aster is shown at the lower pole, and also at the lower pole of Fig. 3 .

Fig. 5, from the spermogonium of Uromyces Lilii, although somewhat ill-defined and difficult of interpretation, apparently represents a stage next in order of development. The long axial strand is probably the central spindle, while the mantle fibres, particularly at the lower pole, suggest a late anaphase. It is of interest to observe in this figure that, although mitosis is somewhat far advanced, the dividing nucleus has not yet passed into the end of the filament, where the spermatial bud is already well formed. Herein this form on Lilium differs markedly from Triphragmium, in which the nucleus, when in quite an early stage of mitosis, moves upward into the very tip of the budding spermatium (see Figs. 2, 3, 4, 6).

A late anaphase of the spermogonial nuclei of Triphragmium is represented in Fig. 6. Such a figure is perhaps most often met with, presumably because its sharply-defined poles so easily catch the eye. Only a few obscure filaments now remain of the central spindle. But the mantle fibres, on the other hand, are at this stage so conspicuous that they can be quite easily and accurately counted. In Fig. $6 a$, for example, a daughternucleus in anaphase condition is drawn, in which the filaments attached to the poles are seen to number eight. Eight indicates also, in my opinion, the chromosome number for this form.

This last-mentioned figure (Fig. $6 a$ ), which is drawn with a very high magnification, shows most clearly a peculiar phenomenon. The centre is here plainly a double structure, and each half has four clearly-defined strands attached to it. The double nature of the centrosome is also shown at both poles of Fig. 6 , and at the lower pole of Fig. 3. Two possible explanations of this phenomenon are apparent. The doubling has obviously arisen either from a premature division of the centre preparatory to the next division; or else it results from the close proximity in the same nucleus of the chromatin contents of the maternal and paternal nuclei, 
which fused in the teleutospore, a short time before this stage. The great theoretic importance of the latter theory is sufficiently obvious, and will be discussed to a limited extent later in the general part of this paper. No signs of the doubling of the centrosome are to be noticed in the newly reconstructed spermatium nucleus drawn in Fig. 7, nor in Fig. 8, which represents a highly-magnified sporophytic nucleus from the young aecidium of Puccinia Cirsii-lanceolati. So far as can be seen, the centres in each of these figures are single structures. It is at once obvious, particularly in Fig. 8 , that the chromatin is centred on this structure. One end of each of the chromatic filaments is connected with the centre, while the other extends into the nuclear cavity, thus resulting in a polarized condition of the nucleus, similar to that described for certain mildews by Harper ('05).

Fig. 9 is from the spermogonium of Uromyces Scirpi, and represents an equatorial-plate stage. The ill-defined chromatin is massed somewhat excentrically in the equatorial region of the dense spindle. Centrosomes are somewhat obscure in this instance; possibly the broad structure at the lower pole is to be regarded as a sort of pole-plate, or disk-shaped centrosome.

The next three figures show gametophytic nuclei, as is true also of all the figures of nuclei so far described, except Fig. 8. Figs. I-7 and 9, however, are all drawn from spermogonia ; while Figs. Io, IO $a$, and II are from the vegetative hyphae which finally produce the gametes. All three of the latter drawings show the anaphases of the division, by means of which the so-called 'sterile cell' is cut off. Figs. 10 and Io $a$ are from Triphragmium, and Fig. I I is from one of the hyphae from the base of the aecidium-cup of Uromyces Scirpi. In Fig. Io, reconstruction is in process. Above, the centre is obviously double, and about four strands are attached to each half-centre, just as was described for Fig. $6 a$. The daughternucleus below, in Fig. Io, shows an obliquely polar view, so that about eight chromatic filaments can be counted, radiating from the pole. A new nucleole is in process of formation within this latter nucleus. In Fig. Ioa the mitotic figure is apparently rather poorly defined, as is also the late anaphase shown in Fig. II.

Figs. 12-22 show a fairly complete series of stages of the mitoses which take place in the sporophytic cells containing the so-called 'conjugate nuclei'. While considerable growth takes place in the gametophytic hyphae which have just been considered, a greatly increased stimulus to growth is apparent at once on the initiation of the conjugate, or binucleated, condition, through the fusion of two cells. The first step in the rejuvenating sexual process is thus the sudden transition from uninucleated cells to binucleated.

As has been described above, when the cytoplasm of two cells begins to fuse, through the gradual absorption of the wall which separates them, 
the two nuclei begin at once to divide, even before they come to lie close together in the fusion cell. This is proved, as I have already suggested, by the immediate formation of vacuoles in the nucleoles, and by numerous instances in which the nucleoles are cast out into the cytoplasm before the two gamete nuclei have approached each other (as, e.g., in Fig. 32). Such nuclei as are shown in Fig. 35 also illustrate this point. The dumbbellshaped centrosomes in this instance are obviously in a state of division, although cell fusion has only recently taken place, and the two nuclei still lie in the bases of their respective gametes.

Fig. I 2 represents a condition just following cell fusion, although, in this instance, the origin is not shown. The long, budding growth contains the two conjugate nuclei, each of which has begun the prophases of division. Here again, as in Fig. 35, are seen two dumbbell-shaped centrosomes. Each centrosome appears to be contained within the nucleus ; but careful focussing inclines one rather to the belief that it is not an intranuclear structure, but that it lies instead on the surface of the nuclear membrane. Figs. I and 2 show this point more clearly, for there can be no doubt in these instances that the centres, as well as the central spindle which is formed between them, lie, at least for a time, on the nuclear membrane. Further, the connecting isthmus of each dumbbell-shaped structure in Fig. I 2 corresponds, in my opinion, to the long, slender strand, or central spindle, extending between the centres in Fig. 2.

The nuclear membrane soon breaks down, and the nucleole is thus cast out into the cytoplasm, as Figs. I $3^{-1} 5$ show. Apparently this phenomenon is about to take place in one of the nuclei of each of the following figures, I 2, 29, 32, and 34. The central spindle early becomes a strongly-developed structure, apparently of a densely filamentous nature, which stretches between the two diverging centrosomes. The chromatin at this early stage forms an ill-defined, more or less thready mass at one side of the central spindle, much as Hermann and others figured for the nuclei of the Salamander and other animal cells (Figs. I3-I 5, 24).

The central spindle is frequently at first somewhat curved, or bowed in, on the side on which the chromatin is massed, as is shown for certain spindles in Figs. 14 and 24. Further, during the divisions just following conjugation, the two spindles are often variously oriented with respect to each other. In Fig. I4, for example, the two spindles are placed almost at right angles to each other. In Fig. I3, while the mitotic figures are about parallel to each other, they are twisted about so as to lie across the long axis of the cell. In Figs. 15, 17, 18, and 20 the more common position is shown, the two spindles lying parallel to each other and in the long axis of the cells.

An early prophase of conjugate division is shown in Fig. 13. The nucleoles are somewhat near the central spindles, which are at this stage comparatively short. The poles of the spindles are each terminated by 
broad, plate-like centrosomes. A somewhat later stage is shown in Fig. 4I. The nucleoles now lie some distance from their respective spindles. The left nucleus in this figure is particularly well adapted to show the relation which the dense central spindle sustains to the chromatic mass aggregated on its curved side. Mantle fibres are here not well differentiated; but it seems quite likely that they are represented by the few dense filamentous structures which curve from the poles out into the adjacent mass of chromatin.

Fig. I5 shows a somewhat similar stage of conjugate division. The two nucleoles are quite remote from their nuclei, and they show as yet no particular signs of disintegration. The double base of this figure suggests that this is a 'fusion cell', but there are no remnants of a partition wall left to show how such a fusion took place.

While unsatisfactory as to the chromatin, Fig. I 6 shows with remarkable clearness the sharply-delimited spindles. There can be no doubt that here the two spindles are separate and distinct structures, and that they do not fuse into one during division, as was claimed for conjugate divisions by Poirault and Raciborski. The chromatin in this instance has apparently been drawn almost entirely into the central spindle, and it is now in early anaphase condition. The two nucleoles lie near the equator of their respective spindles and are in an advanced stage of dissolution, as is indicated by the large vacuole in each.

While it is sometimes difficult to distinguish the central spindle in the late anaphases, the mantle fibres, on the other hand, stand out sharply. A good part of the fibrous structures which appear between the receding centres in Fig. I 7 probably should be referred to the mantle fibres, since they are chromatic in their staining reactions. In Fig. I8, also, the conspicuous fibres are probably mantle fibres, and the few dim structures, which still persist between the daughter-nuclei, doubtless represent what is left of the central spindle. In many other instances, however, these late stages are characterized by the persistence of a quite conspicuous central spindle. The attenuated structures in Figs. 20 and 2I, for example, which connect the receding daughter-nuclei are plainly central spindles, and the mantle fibre portion in both cases has contracted almost to the poles.

The frequent presence of asters at the poles during these later stages (Figs. I7-19) undoubtedly indicates a totally different sort of polar activity than that which characterizes the earlier stages, since in the latter they are not noticeable see Figs. (I $3-16$ ).

The reconstruction of the daughter-nuclei in these forms has already been described for the gametophytic hyphae, and the process in the binucleated cells is essentially similar. Fig. I9 illustrates quite clearly the phenomenon. The chromatin of each nucleus lies in a clear space, and the strands are arranged with some regularity. One end of each strand is still attached to the centre, while the other apparently ends free in the 
nuclear sap or else anastomoses with other strands. Although a considerable amount of nuclear sap seems to have been already formed in this instance, the nuclear membrane cannot yet be distinguished. As in the cases described above for the gametophytic hyphae, the chromatin strands which radiate from each centre are plainly constant in number, being about eight in each of the three nuclei shown. The fourth and missing nucleus in this cell lies immediately below the one shown in the tip of the hypha.

The large size of the nuclei of Triphragmium is emphasized by a comparison of Fig. I9 with Figs. 20 and 2I, which represent the close of the conjugate divisions in the aecidium of Uromyces Scirpi. All three of these figures are drawn to the same scale. The latter are too small to show the details of the telophases; but the centres, chromatin strands, and central spindles can be made out in properly-stained preparations, and these features will be seen to correspond in every way with those described for the larger and more favourable nuclei.

It will be remembered that Richards ('96) found at the base of the aecidium-cup of the Rust on Ramunculus septentrionalis a single large 'fertile hypha' which contained many nuclei and which budded out to form finally the basal cells. Massee ('88) had previously figured a large severalnucleated cell which he termed the 'oogonium', at the base of the aecidiumcup on Ranunculus Ficaria. Blackman and Fraser ('05) also show drawings of Puccinia Poarum (Figs. 15 and 16 ) in which three and four nuclei are seen in division; but they regard such cases as abnormal.

In the species occurring on Cicuta (Uromyces Scirpi), as well as in six or eight other species, I have found multinucleated cells, sometimes only one, or again many, generally scattered more or less irregularly at the base of the aecidium-cup. Fig. 2 I illustrates one of these cells, which contains four nuclei in an advanced state of division. The parallelism of the four spindles in this case is striking, only one of the nuclei being placed at a slight angle to the others. Notwithstanding this slight displacement, the two pairs of nuclear figures may be still regarded as maintaining their conjugate arrangement. In the later development of the fungus, when two nuclei only occupy the cell, the close proximity and parallelism of the two figures appears to be maintained with the greatest regularity.

Another four-nucleated cell is shown in the next figure (22), from the base of the aecidium on the thistle. Nuclear division has apparently just been completed, since the nuclei show obvious signs of undergoing reconstruction. Three of the nuclei, for example, still have the chromatin massed about their centres.

Much more striking cases of multinucleated cells occur in Figs. 23, 24, and 25 , two of which $(23$ and 25$)$ are from the base of the aecidium on the thistle. Besides the nine poorly differentiated nuclei shown in Fig. 23, three possessing the same characteristics and undoubtedly belonging to the 
same cell are to be found in the next section of the series. Other cells round about the one here illustrated have resting nuclei which seem to be exceedingly well fixed (see, e. g. Fig. 25, in which fifteen such nuclei are shown in one cell), so that the peculiar appearance in this one cell can hardly be said to be due to poor fixation. Although I am not prepared to explain all the details of the mitosis for this form-Puccinia Cirsii-lanceolati-I am fairly certain that such stages as are here represented are early prophases. We have then presented in this instance the peculiar phenomenon of twelve nuclei in the one cell undergoing division at the same time. Further, the variously irregular positions assumed by the figures suggest that the paired, or conjugate, arrangement seen in the binucleated cells is here not at all maintained.

A still more convincing case is shown in Fig. 24, from the basal region of the aecidium on Cicuta, in which the six nuclei here drawn (as well as three additional ones which lie in a lower plane) show clearly the prophases of division, as well as the fact that the spindles maintain no definite paired relation to each other. The various central spindles are oriented in such a heterogeneous fashion with respect to each other that it is difficult to imagine how, in these multiple divisions, there can be any maintenance of a conjugate relation. The principal point to be noted in this place, however, is the fact that where such multinucleated cells occur, the tendency is for the nuclei to divide simultaneously. But that this is not universal in such conditions is indicated by some apparent exceptions which I have found. While it is not the purpose of this paper to discuss the important questions which arise as to the origin of these multinucleated cells, and as to the part they take in the development of the aecidia, I wish merely to add the suggestion that the lack of evident pairing of the nuclei is probably comparable to the somewhat irregular relation seen in the young fusion cells of Triphragmium (Fig. I4), where the paired spindles may at first be variously oriented with respect to each other. It is, of course, possible that we have here multinucleated gametophytic cells, in which we should expect no pairing of the nuclei. But, although convincing evidence is as yet lacking, I am inclined to regard such cells as sporophytic in their origin, and as resulting from the greatly stimulated growth which follows sexual cell fusions.

\section{General Discussion.}

The conjugations by means of which the cells of the Rusts become changed from a uninucleated to a binucleated condition are certainly not to be associated with the simple anastomoses or fusions for nutritive purposes such as occur in the hyphae of many fungi. As Maire, Blackman, and Christman agree, this step in the Rusts marks the beginning of the binucleated condition of the sporophyte generation. The uninucleated 
stage, on the other hand, from the sporidia, or basidiospores, up to the base of the aecidium constitutes the gametophyte generation. Besides the basidiospores, this stage bears only one kind of uninucleated spore-like bodies-the so-called spermatia-which Christman regards as the now functionless gametophytic pycnidia; whereas the sporophyte stage may bear from one to several kinds of binucleated spores. The process of sexual cell fusion which initiates the binucleated condition gives the stimulus of 'fertilization', or the first essential step of the sexual cycle. This is followed, either shortly (in the lepto- and micro-forms) or after a more or less prolonged period of development (in the eu-, brachy-, and hemi-forms), by the other steps of the sexual process, i.e. nuclear fusion, and, according to Blackman, chromatin fusion.

The main question here confronting us involves, therefore, the method of fertilization-as to whether 'a female cell is fertilized by the nucleus of an ordinary vegetative cell', as Blackman maintains; or whether the two fusing cells are equal gametes, as Christman holds. The one evidently interprets the process as tending to the oosporic type and toward the Red Algae; the other holds that two equal gametes fuse to form a non-resting zygospore.

Although in Figs. 28, 3I, and 32 the lower cell appears to be somewhat smaller than the upper gamete, it is sufficiently obvious that such sections as are here represented will not enable one to judge certainly as to the shape and comparative size of the two fusing cells. In his first paper ('04), Blackman makes a strong point of his observation that the lower cell is smaller than the upper cell; and, further, that even the two nuclei in the young fusion cell are unequal in size, remarking that the smaller nucleus is denser and that it shows no nucleole or only a small one. In each of the Figs. $3^{1-33}, 3^{6}$, and 40 , one of the two nuclei likewise appears to be smaller than the other; although the nucleoles are not lacking in these cases, nor are the smaller nuclei conspicuously denser than the others. Some instances of fusing cells which I have observed, in which one of the nuclei appears to be smaller than the other, are undoubtedly to be explained as due simply to the unequal cutting in two of the smaller nucleus; or it may be that an end view of an elongated nucleus is presented. One nucleus, it is true, may, during the passage from one cell to another, be somewhat denser than the other (Figs. 33 and 34) ; but, in my opinion, there are no differences in shape or size, either between the two fusing cells or between their nuclei, which cannot reasonably be explained as due to sectioning or to greater or less rotundity of the nuclei.

It is clear, therefore, to my mind, that Christman's contention as to the equality of the two fusing protoplasts will hold, at least for the four species herein considered. Hence Blackman's interpretation of one of the cells as a differentiated 'fertile, or female' will not apply in these cases. But 
the latter's conception of fertilization by means of ' nuclear migration ' has, in my opinion, some basis in fact, since, during the earlier stages of cell fusion, one of the two nuclei may undoubtedly sometimes be seen to pass through a very narrow opening into the adjoining gamete (Figs. 33 and 34). But a multitude of other cases in which a broad fusion pore is formed (Figs. 26-33, 37-40) proves that the nuclei are not alone involved, and that the cytoplasm of the two cells also fuses into one mass. As indicated above, the occurrence of both the Blackman and Christman types of fusion (Figs. 34 and $3^{6}$ ) near each other in the same preparation shows conclusively that appearances which suggest a 'nuclear migration' through a narrow opening may occur adjacent to a clear case of cell fusion in which a broad conjugation pore has been formed. Since the term 'nuclear migration' has been recently used extensively for undoubted pathological cases in which nuclei are found passing through minute pores in the partition wall ; and, further, since Christman ('07 ${ }^{2}$ ) has shown that similar pathological migrations may sometimes occur between sporophytic cells in Puccinia Podophylli, it seems desirable not to employ the expression 'nuclear migration' for those cases in which, during the earlier part of the sexual cell fusions, the nuclei are seen to pass through narrow openings into the adjoining gametes. Such true sexual fusions as are shown in Figs. 33 and 34, as well as in Blackman's Figs. 66 and 68, certainly resemble strikingly the pathological nuclear migrations figured by Miehe ('01) and Christman ('07 2 ). But the subsequent history of the binucleated series of cells thus sometimes initiated in the Rusts undoubtedly excludes any interpretation of a pathological nature for such cases. To bring such cases into line with Christman's interpretation of a cell fusion, the explanation indicated above appears reasonable, viz. that sometimes the fusion of the two gametes begins through a narrow opening, so that the nucleus in passing through the pore becomes much elongated and constricted. Thus, in the light of the further facts brought out in this paper, the seemingly divergent accounts of Blackman and Christman become, in my opinion, easily reconciled, at least for the diffuse caeoma type of Rusts. But I wish to emphasize at this point Christman's word of caution as to the probable occurrence of nuclear migrations of an undoubted pathological nature in the cup-like aecidia, since I have found a number of cases of migrating nuclei between the multinucleated cells of Puccinia Cirsii-lanceolata. Much still remains to be explained with respect to the aecidium-cup; and in view of the probably regular occurrence of multinucleated cells in young stages of the cup, it seems certain that neither Blackman's ('06) 'nuclear migrations' nor Christman's ('05) cell fusions at the base of every spore-row in Uromyces Caladii will serve to explain all of the complications which appear to prevail in this more highly differentiated type of Rust. 
While I believe, with Christman, that the two fusing cells in the Caeomas are approximately equal, I think that his conception as to the relative position of the two gametes in these forms, as well as their equality, should be somewhat modified and broadened. In all of Christman's figures showing the sexual fusions the two gametes are placed upright and parallel to each other. In my figures illustrating the process (Figs. 26-40) the two cells are seen to occupy various positions to each other. Sometimes the gametes are side by side and parallel; while, perhaps even more often, one appears to be placed below the other, and seems to come up from below at varying angles. Christman further represents each of the fusing gametes as possessing a sterile cell as its tip (see, e.g. his Fig. 4, '05), although the evidence, after a mutual examination of his preparations by the author and by myself, has not convinced me that he is right on this point. Wherever a sterile cell is shown in my figures (Figs. 26-28, 3I, 33, $37,38,40)$, but one gamete is seen to possess such a cell; whereas the lower gamete in these preparations apparently lacks entirely this structure. These observations tend, therefore, to confirm in this one respect those of Blackman, in that he found one gamete only bearing a sterile cell as its tip. It will be remembered that the latter ingeniously suggests that this two-celled structure is a female reproductive organ, the upper sterile cell of which he regards as the now functionless trichogyne, while the lower cell retains its primitive character as a sort of egg, or 'female cell', which is fertilized by what Blackman terms a 'vegetative cell' from below. Blackman points out that the 'sterile cell' sometimes pushes up as a long slender growth between the epidermal cells, thus suggesting, in his opinion, its primitive function when it once pushed its way to the surface and there served as a trichogyne to bring the spermatium into relation with the female cell below.

While I agree to some extent with Blackman's observations of facts, I think that a much simpler interpretation should be applied to such structures than that proposed by him. I should agree with him that but one of the two gametes ordinarily bears a sterile cell, since I have never found convincing evidence that both the fusing cells were thus equipped, as maintained by Christman. In Triphragmium sometimes two such cells will be found in a row at the top of one of the gametes. But whether sterile cells are necessarily present, or whether, on the other hand, they may sometimes be altogether absent, as might be inferred from those drawings of cell fusions in which they are not shown (Figs. 32, 34-36, 39), I am not prepared to say. I believe, however, as indicated above, that in all the caeoma type of Rusts examined by me such a sterile cell is generally present at the tip of one of the gametes. Further study of the pseudoparenchyma in the aecidium-cup type will probably assist materially in the interpretation of these sterile cells, since the pseudo-parenchyma 
cells seem to be cut off in such instances (see Fig. II) more or less indefinitely from certain well-nourished hyphae which line the bottom of the cup. To all appearances this process is quite similar to the cutting off of sterile cells in the caeoma forms.

With Christman, I should regard such sterile cells as having but little phylogenetic significance, and as serving merely as 'buffer' cells', to assist in rupturing the epidermis. Such sterile tips, at least in the case of the caeoma type of Rust, are clearly gametophytic cells which finally die from lack of food, or which fail of fertilization. But the presence of a sterile cell at the tip of only one of the fusing cells in the caeoma and not on the other has, in my opinion, an important physiological significance which has not heretofore been pointed out. This phenomenon indicates, to my mind, that those hyphae which bear such cells at their apices grow up from below some time before those hyphae which do not possess such a structure. The first gametophytic cells to group themselves more or less regularly upright and parallel under the epidermis of the host, apparently thus grow vegetatively for a time and cut off sterile tips; but so far as my observation goes, these early hyphae do not fuse among themselves. Other distinct hyphae appear to grow up later from below and to press in between the earlier growths, thus providing the fertilizing gametes. That the conjugating pairs of gametes are thus differentiated in time of development, is clearly indicated by the two highly significant facts noted above; viz., that one of the gametes bears a sterile cell while the other does not, and, secondly, that one gamete, in my experience, generally lies somewhat below the other. To these points might be added also the important fact that after the earlier hyphae are grouped under the epidermis a period of considerable duration undoubtedly elapses before the binucleated condition arises.

These facts, in my opinion, point to the interpretation just mentioned as a more simple and reasonable one than that proposed by Blackman. The latter's idea that the sterile cells are abortive trichogynes, while of great interest and theoretic importance, has therefore but little basis in fact.

It is quite evident that the nuclear divisions described above are to be classed as indirect divisions rather than amitotic, as Blackman regards them in the forms he has investigated. The latter author studied examples in which the chromatin in each vegetative nucleus was fused together so as to form a dumbbell-shaped mass and was otherwise poorly differentiated during division. Such a condition is apparently common among Rusts, since every one of the previous investigators who had studied the subject described similar appearances to those he figures. Holden and Harper probably rightly conclude that, in such vegetative mitoses, poor fixation must be responsible for the lack of differentiation. Blackman, on 
the other hand, concludes that chromosome-formation in these cases 'is in complete abeyance ; so that the division actually partakes of the nature of direct division' ('04, p. 356). In all the various types of Rust cells herein described - in those of the spermogonium and in the uninucleated cells of the gametophyte, as well as in the binucleated cells of the sporophyte-the mitoses are found to conform quite closely to the type figured by Hermann for the Salamander. All three of the species which I have carefully examined for the mitotic phenomena agree in this respect; and, although it is true that the nuclei of various species of Rusts vary greatly in size as well as in favourableness for study of the details of the process, it is highly probable that the phenomena as observed in Triphragmium will be found to be characteristic for the group.

As was described above for Triphragmium, the central spindle arises between the halves of the divided centrosome. Further, since the centrosome is located on the nuclear membrane, in a somewhat similar position to that occupied by the centre in Phyllactinia (Harper, '05), the central spindle comes to be formed in a corresponding position, along the nuclear membrane (Figs. I-4). Soon the nuclear membrane breaks down and the central spindle thus comes to lie as a dense, strongly-developed structure at one side of the irregular mass of chromatin (Figs. 13-15, 24). It will be remembered that Blackman thinks that the spindles in the case of the promycelial divisions in Gymnosporangium are formed outside of the nucleus, free in the cytoplasm, between the two portions of a divided extra-nuclear centrosome. His figure illustrating the phenomenon resembles closely the nuclei of my Fig. 24. From the facts gained from a study of the earliest prophases in the spermogonium of Triphragmium, I am inclined to think that Blackman has missed the earliest stages of spindleformation. It is quite probable, in my opinion, that Gymnosporangium will be found to agree with Triphragmium in having the centre located on the nuclear membrane, during the earlier stages, instead of outside the nucleus, in the cytoplasm. On the breaking down of the nuclear membrane, an appearance similar to Blackman's figure would then be presented. It is highly probable, further, that the description of the nuclear and cell division in the spermogonium of Phragmidium violaceum given by Blackman will be found to be based on poor preparations, since both processes in the case of the spermogonium of Triphragmium are perfectly normal and well differentiated. The division of the spermogonial nucleus in Triphragmium corresponds in all the essential features to the mitoses in other types of cells of this species ; and further, the cell division by means of which the spermatium is cut off presents no such peculiarities as Blackman describes. The latter figures a sort of thickening ring on the hyphal wall below the constriction which he thinks may somehow be connected with the disjunction of the spermatium. This ring does not 
appear at all in Triphragmium; on the contrary, cell division takes place by means of the usual process of constriction.

Blackman's idea that we have in the Rusts three distinct kinds of nuclear division--the vegetative division, in the spermogonium and in the vegetative hyphae, which he regards as of the nature of amitosis; and the two promycelial divisions, which he thinks are reduced forms of indirect division-is apparently based on the study of unfavourable material. I have not yet compared the nuclear division in the promycelium of Triphragmium with the vegetative divisions of this form; but since the latter are found to conform in the main features with the mitotic phenomena as described for other organisms, I think it more than likely that the promycelial and vegetative divisions in the Rusts will be found to differ from each other only in those characteristics which distinguish the heterotypic and homoeotypic divisions from the vegetative.

In Triphragmium the fibrous structures seen in the telophases, which represent the chromosomes, are seen to number invariably eight (Figs. $6 a$ and Io). Poirault and Raciborski's ('95) conception as to the single longitudinally-split chromosome of the Rust nuclei, as well as Sappin-Trouffy's ('96), and Maire's ('00) conclusion that the two chromatin masses so commonly ob served represent two chromosomes, results without doubt from the study of poorly-differentiated mitotic figures. The well-differentiated nuclear figures obtained in the vegetative cells of Triphragmium, as well as the occasional favourable cases in some other forms, furnish convincing evidence of the correctness of Holden and Harper's view that the more or less solid dumbbell-shaped chromatin masses, characteristic of the vegetative nuclei of so many Rusts, result from poor fixation and poor differentiation. Blackman ('04) also regards the two chromatin masses in each nucleus as resulting from poor differentiation. He did not succeed, however, in making out distinct chromosomes; nor did he see more than a 'simple spindle' in the achromatic structures.

Blackman offers without further comment the pregnant suggestion that the two chromatin masses first noted by Sappin-Trouffy ' probably represent the chromatin derived respectively from the two nuclei which fuse in the teleutospore' ('04, p. 346). The double centres seen in Figs. 6, 6a, and Io, to each of which four chromosomes are seen to be attached, result, in my opinion, from this tendency for the chromatin contents of each daughternucleus to segregate into two more or less distinct masses. But to the views expressed in certain recent important investigations on related problems bearing on the cytological aspects of heredity in the higher plants (Allen, '05; Strasburger-Allen-Miyake-Overton, '05) Blackman's theory would present a striking contrast. The double character of the nuclei in the case of higher plants, resulting from the close proximity in the same nucleus of the chromatin derived from the two parents, clearly persists 
throughout the sporophytic development. But here, in the Rusts, Blackman would have a doubling to result from a similar origin and to persist as well throughout the gametophyte. The nuclei of the vegetative gametophytic hyphae (Fig. 10), as well as those of the spermogonium (Figs. 6 and $6 a$ ), clearly show in some instances this phenomenon. The nuclear fusion in the teleutospore and the two promycelial divisions which presumably accomplish the reduction processes, have occurred but a short time before in the development of the fungus. While Blackman's conclusion might therefore seem to be the natural one under the circumstances, viz. that the double character of the nuclei results from the continued association of the same nuclear cavity of the chromatin derived from the two nuclei which have just fused in the teleutospore, the important bearing of such a theory and its lack of harmony with the recent theoretical work on the higher plants above mentioned, compels us to await more facts before accepting his conclusion. Another view is possible to explain the phenomenon. The double centre may be reasonably explained as resulting from a precocious division of the centre in each daughter-nucleus, in preparation for the next mitotic division-a phenomenon which has already been described as taking place in the nuclei of a number of organisms.

While not yet prepared, as indicated above, to discuss fully the important questions which arise as to the mode of origin of the multinucleated cells at the base of the aecidium-cup, nor as to the part they bear in the development of the aecidia, it may be advisable in this place to point out a few pertinent facts and theories. Massee ('88) claims to have seen such a multinucleated cell at the base of the aecidium-cup, which he thinks resulted from the fertilization of an oogonium by an antheridium. Richards ('95) has figured in a similar position one, or in large cups often more, large, sometimes multinucleated cells, which, according to him, give rise by budding to the basal cells at the bottom of the spore-rows. Richards thought that the multinucleated cells arose simply by the swelling up and growth of one or more special 'fertile hyphae' at the base of the cup. Blackman ('04 and '06) saw a number of cases in young aecidia in which the cells had three and four nuclei, but he regarded such isolated instances as abnormal.

That multinucleated cells are formed, probably as regular occurrences during the earlier stages in the development of the young aecidia, is indicated by their discovery, during the course of this investigation, in at least eight or ten species of Rusts. I am therefore convinced that they are perfectly normal occurrences, and that they result simply from the nuclear divisions going on much faster and thus getting ahead of cell division. Even in the caeoma form-Triphragmium ulmariae-instances, probably of a similar nature, have been occasionally noted in which five or six nuclei occur in one cell, although but two is the usual number.

Whether such multinucleated cells result from the stimulated growth 
which follows the sexual cell fusions, or whether they are formed during the gametophytic stage, preceding the fusions, I am not prepared to say. The studies so far made on this point are only partly convincing; but, as mentioned above, the few facts at my command incline me to the belief that the multinucleated cells are sporophytic structures and that they result from the stimulated growth that follows the sexual cell fusions. Leaving aside for the present, however, the question of their origin, it is quite obvious that their seemingly normal and regular occurrence during the development of the young aecidia argues strongly against the acceptance of either Blackman's or Christman's ideas as to the mode of origin of the binucleated condition in the aecidium-cup Rust. At any rate, it is evident that further investigations of the minute structure and development of further types of the aecidium is needed before we can hope to bring this more complicated type into relation with the simpler caeomas.

\section{Summary of Results ANd Conclusions.}

I. The seemingly conflicting results obtained by Blackman and Christman, in their investigations of the sexual phenomena in the caeoma type of Rusts, are to some extent brought into harmony by certain new and supplementary facts recorded in the present paper. The two fusing gametes, as well as their nuclei, are regarded, however, as approximately equal, therein affording in greater part a confirmation of Christman's conclusions. While agreeing also with some of Blackman's observations of facts, certain of his conclusions with regard to these observations are not supported; e.g. that one of the fusing cells is generally smaller than the other, and that this smaller cell, which he thought contained a smaller, denser nucleus, is to be regarded as a 'vegetative cell', as distinct from the larger ' fertile cell'. Blackman's further theory that his so-called larger cell constitutes a 'female cell', and that its sterile tip is phylogenetically a 'trichogyne' also lacks support in the facts brought out in this investigation.

While the conjugation is therefore regarded as taking place between two gametes which are essentially similar in size, several observations in connexion with the sexual fusions, apparently noted only in part by Blackman and Christman, point to the conclusion that the two gametes differ somewhat in time of development. The observations on which this conclusion is based are as follows: (I) In the caeoma forms the first hyphae to push up under the epidermis mass themselves often more or less regularly upright and parallel and then proceed to cut off sterile cells at their tips. The sterile tips push up against the epidermal cells and soon degenerate. A more or less prolonged period of vegetation appears thus to intervene before the conjugations begin. (2) Generally only one of the two conjugating gametes bears such a sterile tip, while the other shows no such 
differentiation. (3) The gamete which bears the degenerating tip-cell often appears to be placed somewhat above the other, thus suggesting that the earlier hyphae fuse, not among themselves, but with other hyphae which push up later from below.

This explanation appears simpler and more reasonable to the writer than the complicated theory proposed by Blackman. The sterile cell, according to the views advanced in the present paper, is not an abortive, functionless trichogyne, but merely a 'buffer cell'-a degenerate gametophytic cell, morphologically similar to the functional gametes. The simpler theory of course leaves the so-called spermatia as yet unexplained.

Conjugation is accomplished, as Christman maintains, through the absorption of a portion of the walls of the two gametes which are in contact. The process may begin, however, through a very small conjugation pore, so that as the one protoplast moves through the narrow opening to fuse with the adjoining gamete, the nucleus may thus sometimes be drawn out and constricted ; in this condition presenting the appearance which Blackman has termed 'nuclear migration'. Such an instance is regarded, however, merely as a case of conjugation of two cells in which the connecting pore is as yet small. Instances were observed in which a Blackman type of conjugation, as it may be termed, through a narrow pore, occurred side by side with a Christman type of fusion, through a broad pore. The essential feature of the conjugation process in the caeoma forms is therefore regarded as the equal participation of two morphologically equivalent cells to form a binucleated double cell-the so-called 'fusion cell'.

2. In the present investigation, the vegetative nuclear divisions have been studied in the spermogonia and in other gametophytic hyphae, as well as in the binucleated sporophytic hyphae. The process is essentially the same in all these types of cells, being a mitotic phenomenon, and not partaking of the nature of amitosis, as Blackman claims for the nuclei of Phragmidium. Each nucleus, during the conjugate divisions, acts apparently in entire independence of its associated nucleus. During the earlier stages of the association of the two nuclei in the one cell, just following the sexual fusion, the mitotic figures may sometimes be variously oriented in the cell, bearing no obvious relation to each other. Later, however, the two conjugate spindles generally arrange themselves more or less regularly parallel to each other in the long axis of the cell.

Each nucleus divides by the aid of a centrosome, which is located on the nuclear membrane, and which in some forms persists in the resting stages as a distinct point of polarization of the nuclear contents. During the prophases, the centre divides and the two daughter-centres move apart on the nuclear membrane. Between the diverging centres a filamentous structure appears-the central spindle of Hermann. Soon the nuclear membrane breaks down and the central spindle comes to lie as a dense, 
thready structure at one side of the chromatic mass. Mantle fibres now extend out from the diverging polar centrosomes to the chromatin and accomplish the division into the two daughter-halves. During the later phases, a few polar radiations generally appear.

While the chromosomes in the case of Triphragmium are not sufficiently differentiated in the equatorial-plate stages to be definitely counted, during the anaphases, however, the chromatic radiations which converge to the poles become quite distinct and are then seen to number eight. These chromatic strands are regarded as corresponding to chromosomes. Further, they are often seen to be segregated into two distinct groups of four each, and each group is seen to be attached to a distinct centrosome. This double character of the daughter-nucleus is interpreted as expressing in somewhat clearer terms the doubling noted by several earlier writers. Rather, however, than denoting the longitudinal splitting of a single centrosome, as held by Poirault and Raciborski ; or the existence side by side in the one nucleus of two distinct chromosomes (Sappin-Trouffy and Maire) ; or the presence in the same reduced nucleus of the chromatin derived from the two parents (Blackman), it is suggested that the double character may result from a precocious division of the centre, in preparation for the next mitosis.

3. The apparently normal and regular occurrence at the base of certain young aecidia of one to many multinucleated cells, points to the necessity of a broader conception as to the mode of development of the aecidium-cup than that held by either Blackman or Christman. While the part which these multinucleated cells take in the development of the aecidium is as yet somewhat obscure, the evidence appears to point to the conclusion that they are sporophytic structures and that they result from the stimulated growth which follows the sexual cell fusions. Should this prove true, it is obvious that the 'fusion cell' does not at once function as a 'basal cell', at the bottom of each spore-row, as maintained by Christman for this type of Rust. Further, the occurrence of occasional instances suggesting 'nuclear migrations', undoubtedly of a pathological nature, between the multinucleated cells of Puccinia Cirsii-lanceolati, throw doubt on the idea as to the normal origin of the binucleated condition in the aecidium-cup by this means. ${ }^{1}$ State College of Agriculture and Mechanic Arts,
Brookings, South Dakota.

November, I907.

${ }^{1}$ Since the above went to press, two papers on the subject (The Relation of 'Conjugation' and 'Nuclear Migration' in the Rusts; and The Relationships of the Aecidium-cup Type of Rust) were read by the writer before the Chicago meeting (1908) of the American Association for the Advancement of Science, abstracts of which are to be found in Science XXVII : 2 I $^{-1} 5$, Feb. $7,1908$. 


\section{LITERATURE.}

Allen, C. E. ('05): Nuclear Division in the Pollen Mother-cells of Lilium canadense. Ann. Bot., xix, I $89^{-2} 5^{8}$, Pls. VI-IX.

Blackman, V. H. ('04): On the Fertilization, Alternation of Generations, and general Cytology of the Uredineae. Ann. Bot., xviii, 323-73, Pls. XXI-XXIV.

Blackman, V. H., and Fraser, Miss H. C. I. ('06): Further Studies on the Sexuality of the Uredineae. Ann. Bot., xx, 35-48, Pls. III and IV.

Christman, A. H. ('05)! Sexual Reproduction in the Rusts. Bot. Gaz., xxxix, 267-74.

( $\left(07^{1}\right)$ : The Nature and Development of the Primary Uredospore. Trans. Wis.

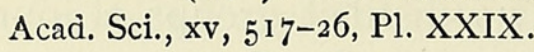
Rusts. Bot. Gaz., xliv, 8I-IOI, Pl. VII.

HARper, R. A. ('05): Sexual Reproduction and the Organization of the Nucleus in certain Mildews. Publ. No. 37. Carnegie Inst. of Washington.

Hermann, F. ('91): Beitrag zur Lehre von der Entstehung der karyokinetischen Spindel. Arch. f. mikr. Anat., xxxvii, 569 .

Holden, R. J., and HARPer, R. A. ('03): Nuclear Division and Nuclear Fusion in Coleosporium sonchi-arvensis. Trans. Wis. Acad. Sci., xiv, $63-77$.

Juel, H. O. ('98): Die Kerntheilungen in den Basidien und die Phylogenie der Basidiomyceten. Jahr. für wiss. Bot., xxxii. $3^{6 \mathrm{I}}$.

Maire, R. ('00): L'évolution nucléaire chez les Endophyllum. Jour. de Botanique, xiv, 80-92, $369-82$.

Massee, G. ('88): On the Presence of Sexual Organs in the Aecidium. Ann. Bot., ii, 47-50.

Miene, H. ('01) : Ueber die Wanderungen des pflanzlichen Zellkernes. Flora, lxxxviii, I05-4I.

Poirault, G., and Raciborski, M. ('95) : Sur les noyaux des Urédinées. Jour. de Botanique, ix, 3 I $8-32,38 \mathrm{I}-88, \mathrm{Pl}$. VI.

Richards, H. M. ('96): On some Points in the Development of Aecidia. Proc. Amer. Acad. Arts and Sci., xxxi, $255-70$.

Rosen, F. ('92): Studien über die Kerne und die Membranbildung bei Myxomyceten und Pilzen. Cohn's Beiträge. JV. 237-66.

Sappin-Trouffy, P. ('96): Recherches histologiques sur la famille des Urédinées. Le Botaniste, $\mathrm{v}, 59-244$.

Strasburger-Allen-Miyake-Overton ('05): Histologische Beiträge zur Vererbungsfrage. Jahrb. f. wiss. Bot., xlii.

\section{EXPLANATION OF PLATE XXII.}

\section{Illustrating Professor Olive's paper on the Rusts.}

All the figures were drawn with the aid of the camera lucida, and, except the few specially noted below, with Zeiss Apo. Obj. $2 \mathrm{~mm}$. N. A. I : 30, combined with Compens. Oc. I 2, thus securing a magnification of 1500 diameters. Various Compensating Oculars, combined with the Apo. Obj. $2 \mathrm{~mm}$. N. A. I : 40, were used for those figures in which the magnification is specially designated.

(Except where otherwise stated, all figures are drawn from Triphragmium ulmariae.)

Fig. I. Nucleus from a spermogonium, showing on the nuclear membrane and enclosed in an archoplasm-like substance, two deeply-stained centrosomes, on each of which a certain amount of chromatin is centred.

Fig. 2. Dividing centres, connected by a slender strand-the central spindle. The nuclear 
membrane appears to be still intact, and the centres and the central spindle are evidently on its upper surface.

Fig. 3. The central spindle now reaches to the poles of the figure. The lower pole is obviously double. The chromatin and nuclear sap lie mainly in the swollen lower half of the mitotic figure, while the upper part, in the forming spermatium, appears to be made up almost entirely of a fibrous material. $\times 225^{\circ}$.

Fig. 4. Early anaphase. The densely fibrous central spindle is at one side of the axis of the figure. The chromatin is being drawn to the poles somewhat irregularly. The lower pole shows some astral radiations.

Fig. 5. Poorly differentiated late anaphase, from the spermogonium of Uromyces Lilii, showing central spindle, mantle fibres, budding spermatium, \&c. $\times 2250$.

Fig. 6. Late anaphase, from Triphragmium, showing at both poles the double centres and mantle fibres. The two fibres which extend between the daughter-nuclei are probably a remnant of the central spindle.

Fig. $6 a$. A double centre, more highly magnified, showing four chromatic strands attached to each half, thus making eight chromosomes to the daughter-nucleus. $\times 2250$.

Fig. 7. A spermatium, showing its comparatively large nucleus, with a nucleole and centrosome. $\times 2250$.

Fig. 8. A highly magnified resting (?) nucleus from a multinucleated sporophytic cell of Puccinia Cirsii-lanceolati, showing the polarized condition. $\times 3375$.

Fig. 9. Poorly defined equatorial-plate stage of division, from the spermogonium of Uromyces Scirpi. $\times 2250$.

Fig. ro. Telophase of the mitosis in the gametophytic hypha which cuts off the so-called 'sterile cell'. The centre in the upper nucleus is distinctly double, and four chromosomes are attached to each half. The lower nucleus is seen in obliquely polar view, so that here also about eight chromosomes may be counted, radiating from the centrosome.

Fig. Io $a$. Anaphase of a similar nuclear division.

Fig. II. Telophase of a mitosis in a gametophytic hypha at the base of the aecidium-cup of Uromyces Scirpi. The uninucleated cell which will be cut off at the tip will form a 'pseudo. parenchyma' cell.

Fig. I2. Prophases of a conjugate division in a fusion cell. The nucleole is apparently about to be cast out from the left nucleus. Each nucleus shows (probably on its surface) a dumbbellshaped, dividing centrosome. The strand connecting the two centres doubtless represents an eariy stage of the central spindle.

Fig. I3. Prophases of conjugate division showing the two nucleoles which have been cast out into the cytoplasm; the two central spindles, the poles of which are each terminated by a diskshaped centrosome ; and the mass of chromatin attached to each spindle.

Fig. 14. A later stage in which the two spindles lie almost at right angles to each other. The nuclear figure at the left is well oriented to show the dense, curving, central spindle, terminated by broad centrosomes, and a few mantle fibres, which reach out from the central spindle, apparently to pull the chromatin finally to the poles.

Fig. I5. The double base suggests that two cells have here fused to form the budding 'basal cell', although no partially absorbed walls remain to confirm the suspicion. The stage in conjugate division here represented is somewhat similar to that shown in Fig. I4. The central spindles in this instance are, however, unlike the latter case, placed parallel to each other.

Fig. I6. Early anaphase stage of conjugate division in a young peridial cell from the aecidiumcup of Uromyces Scirpi. The two nucleoles lie near the equator of the central spindles, a position very commonly assumed in conjugate division. The chromatin in this instance shows the usual poor differentiation which seems to be characteristic for vegetative divisions. $\times 225^{\circ}$.

Fig. I7. Late anaphase, showing broad-poled spindles, mantle fibres, asters, and vacuolated nucleoles.

Fig. I8. Still later stage of conjugate division. The upper right-hand nucleus has a very conspicuous double centrosome.

Fig. 19. Telophase of conjugate division. About eight chromosomes may be counted, radiating from the centre in each nucleus. The companion of the right nucleus lies in a lower plane.

Fig. 20. Late stage of conjugate division in a basal cell from the aecidium on Cicuta. Note the centres, the remnant of the central spindle, \&c. 
Fig. 21. Telophase of a double conjugate division in the Cicuta aecidium. The paised arrangement of the four spindles $\mathrm{i}$ apparently only partially maintained.

Fig. 22. Four reconstructing daughter-nuclei in a basal cell of Puccinia Cirsii-lanceolati. In three of the nuclei the centres still have an aggregation of chromatin about them.

Fig. 23. Simultaneous multiple division in a multinucleated cell at the base of the aecidium of Puccinia Cirsii-lanceolati. Besides the nine poorly differentiated nuclei shown in the figure, three are to be found, belonging to this same cell, in the next section. No paired, or conjugate, relation of the nuclei is here apparent.

Fig. 24. Simultaneous division of six nuclei (three more lie in a lower plane and are consequently not shown in the drawing) in a multinucleated cell at the base of the aecidium-cup of Uromyces Scirpi. The four upper mitotic figures show clearly the irregular mass of chromatin attached to one side of each central spindle. Here again no paired arrangement is apparent.

Fig. 25. A multinucleated cell, from the base of the aecidium on the Thistle. $\times 960$.

(Figs. 26-40, showing sexual cell fusions, have been so oriented that the upper part of each figure points toward the top of the plate as toward the epidermis of the host.)

Fig. 26. Two pairs of fusing cells. Above the upper gamete of the right pair is a 'sterile cell'.

Fig. 27. Fusion of two cells, and the apparent migration of one nucleus over into the right half of the 'fusion cell'. A large degenerating sterile cell has been cut off from the tip of the right gamete.

Fig. 28. Cell fusion, in which the lower of the two gametes apparently arises from a hypha which comes up obliquely toward the eye. A budding growth has pushed out above, to one side of the sterile cell, before the passage of the lower nucleus into the upper part of the fusion cell.

Fig. 29. Basal fusion cell, showing, below, the remnant of the absorbed partition wall which formerly separated the two gametes. One spore 'mother-cell' has been budded off and a second bud has started off to the left. A detached, crushed sterile cell lies between the two buds; whether this originally tipped the upper of the two gametes is uncertain.

Fig. 30. The partially-absorbed partition wall which once separated the two gametes is here seen to be peculiarly bent and contorted.

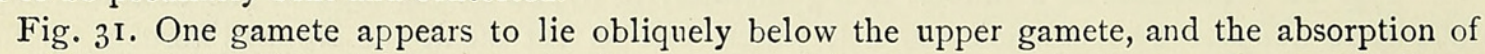
the wall separating them has apparently just begun. The upper gamete bears an unusually large sterile cell, the contents of which, excepting the nucleole, appear to have almost entirely degenerated.

Fig. 32. Fusion cell in which the conjugation pore is clearly shown. The two conjugate nuclei have entered upon the prophases of division, as evidenced by the fact that one nucleus has cast out its nucleole and left it behind in the lower gamete.

Fig. 33. An instance of cell fusion in which the nucleus of the lower gamete has just begun to pass through a very small pore into the upper gamete.

Fig. 34. A similar instance, in Gymnoconia interstitialis, in which more than half of the lower nucleus has passed through a small conjugation pore. The conjugating hyphae are evidently obliquely placed with respect to each other.

Fig. 35. Cell fusion in Gymnoconia in which the two conjugating cells lie side by side and parallel to each other. One has grown up a little higher than the other. A dense, finely granular aggregation of protoplasm lies in the fusion cell where the conjugation pore was formed. The centrosome of each nucleus is dumbbell-shaped and is in process of division.

Fig. 36. A similar fusion cell in Gymnoconia, from the same preparation as the one shown in Fig. 34.

Fig. 37. The beginning of the formation of the conjugation pore in Phragmidium potentillaecanadensis. A deeply staining body, somewhat similar to a nucleole, lies in the pore.

Fig. 38. Fusion cell in Phragmidium potentillae-canadensis, which has begun to grow out to one side of the sterile cell.

Fig. 39. Fusing tips of two hyphae of the micro-form, Puccinia transformans. Excepting for their nucleoles, the two nuclei are poorly differentiated.

Fig. 40. Cell fusion in Puccinia transformans, in which an end cell of one hypha has fused with a penultimate cell of another hypha. 
Annals of Botany
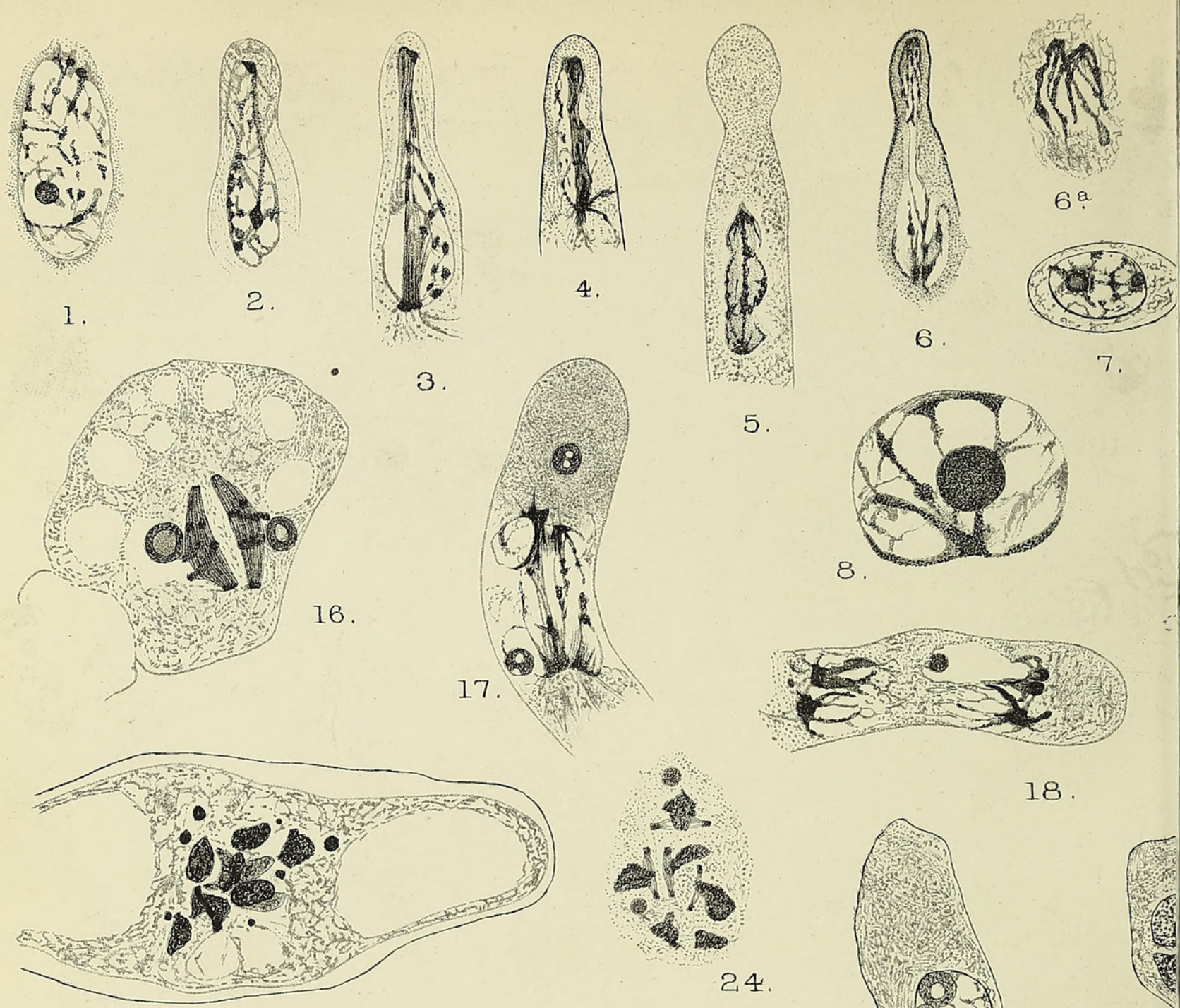

23
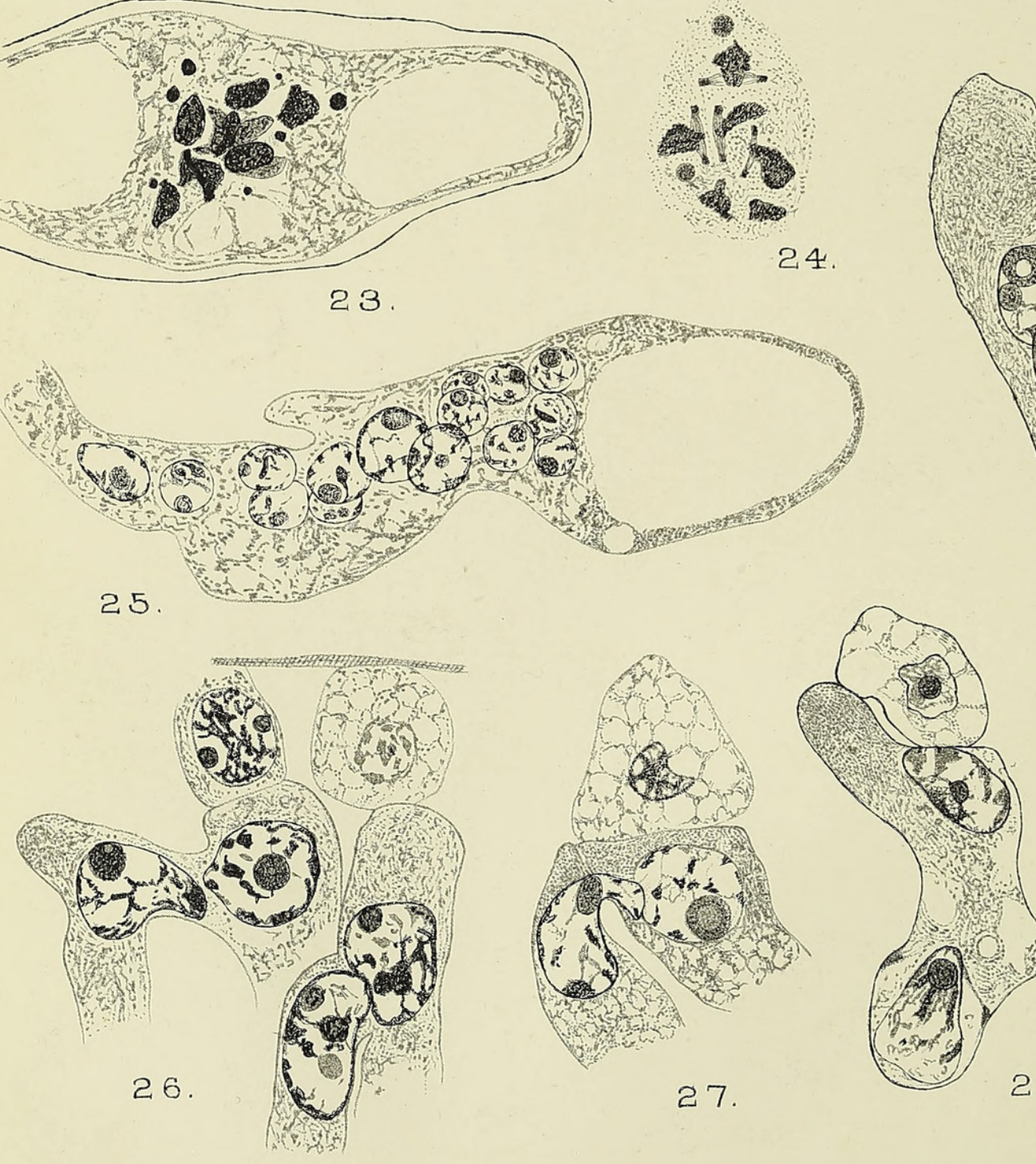

18.
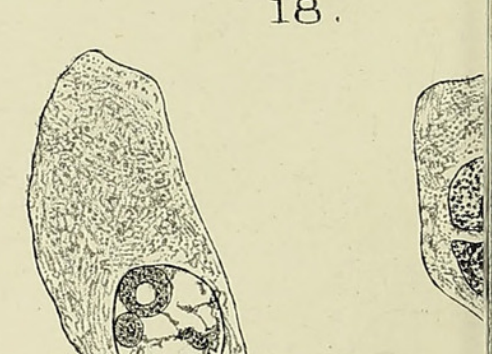


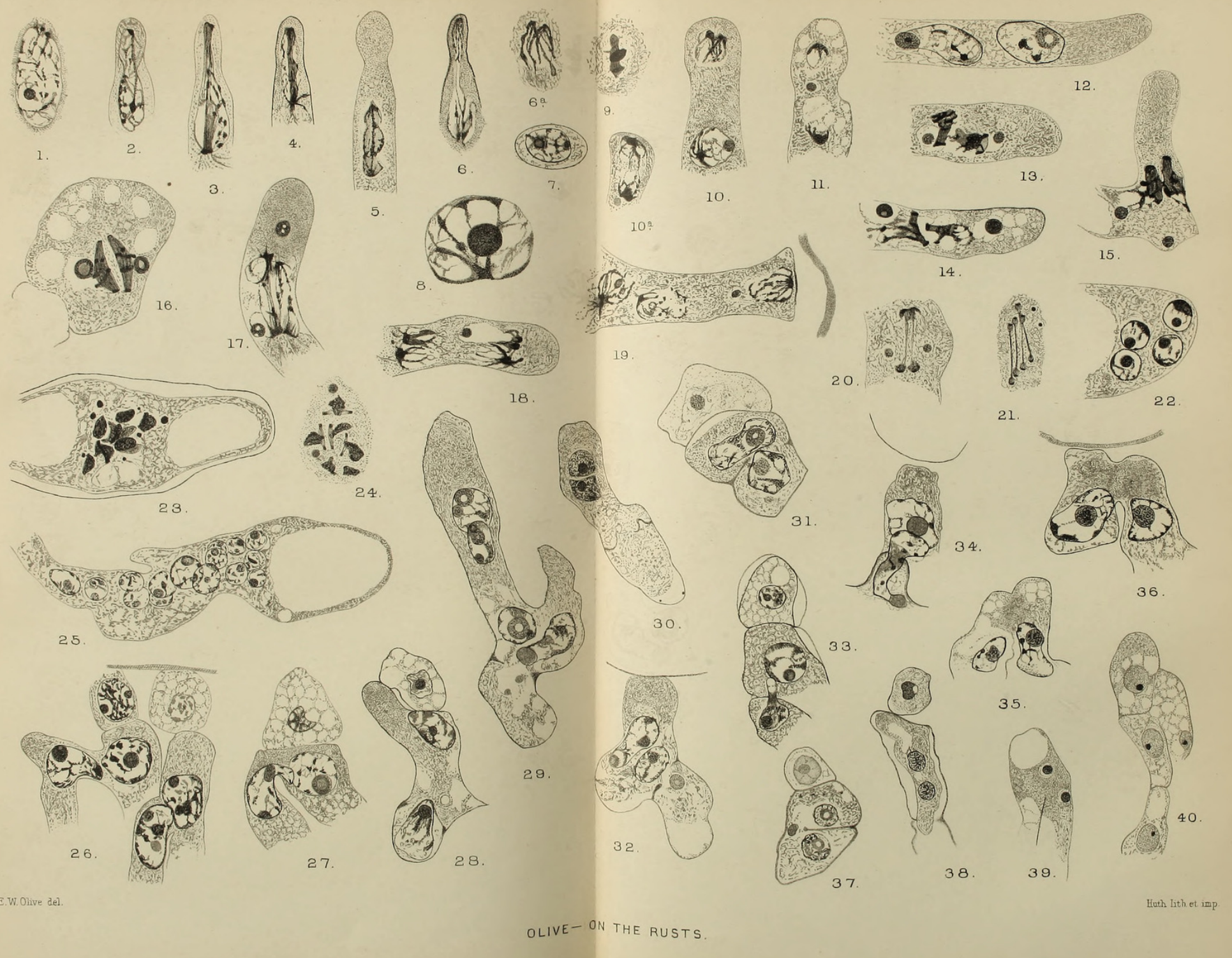




\section{$2 \mathrm{BHL}$ Biodiversity Heritage Library}

Olive, Edgar W . 1908. "Sexual cell fusions and vegetative nuclear divisions in the rusts." Annals of botany 22, 331-360.

https://doi.org/10.1093/oxfordjournals.aob.a089177.

View This Item Online: https://www.biodiversitylibrary.org/item/232525

DOI: https://doi.org/10.1093/oxfordjournals.aob.a089177

Permalink: https://www.biodiversitylibrary.org/partpdf/318913

\section{Holding Institution}

Smithsonian Libraries

\section{Sponsored by}

Biodiversity Heritage Library

\section{Copyright \& Reuse}

Copyright Status: Not in copyright. The BHL knows of no copyright restrictions on this item.

This document was created from content at the Biodiversity Heritage Library, the world's largest open access digital library for biodiversity literature and archives. Visit BHL at https://www.biodiversitylibrary.org. 